Article

\title{
Fluoride Risk Assessment from Consumption of Different Foods Commercialized in a European Region
}

\author{
Juan R. Jaudenes, Ángel J. Gutiérrez *®D, Soraya Paz, Carmen Rubio® and Arturo Hardisson \\ Department of Toxicology, Universidad de La Laguna, 38071 La Laguna, Spain; \\ juanrafarma@hotmail.com (J.R.J.); spazmont@ull.edu.es (S.P.); crubio@ull.edu.es (C.R.); atorre@ull.edu.es (A.H.) \\ * Correspondence: ajguti@ull.edu.es; Tel.: +34-922318905
}

Received: 29 August 2020; Accepted: 15 September 2020; Published: 21 September 2020

\begin{abstract}
Fluoride is a halogen found in soil and water from natural and anthropogenic sources. Foods, such as cereals, fruits, and vegetables, among others, absorb and accumulate fluoride. High intakes of this element produce toxic effects such as dental or skeletal fluorosis. Fluoride content was determined in a total of 144 samples from different food groups (cereals and derivatives, fruits, tree nuts, dry fruits, mushrooms, vegetables, and legumes) using selective fluoride ion potentiometry. The fluoride concentration stood out in almonds $(3.70 \pm 0.96 \mathrm{mg} / \mathrm{kg})$, walnuts $(3.53 \pm 0.62 \mathrm{mg} / \mathrm{kg})$, bread $(2.54 \pm 0.85 \mathrm{mg} / \mathrm{kg})$, and rice $(2.28 \pm 0.93 \mathrm{mg} / \mathrm{kg})$. Consumption of $236 \mathrm{~g} /$ day of bread or $263 \mathrm{~g} /$ day of rice represents $100 \%$ of the recommended daily intake (DRI) set at $0.6 \mathrm{mg} /$ day for children aged 1-3 years. In the case of rice consumption by children of these ages, it is recommended to use bottled water for rice preparation. The consumption of the analyzed foods by teenagers and adults does not pose a health risk.
\end{abstract}

Keywords: fluoride; human exposure; risk assessment; food

\section{Introduction}

Fluorine is a highly electronegative chemical element necessary for the human organism. It is widely distributed in nature as part of minerals, as well as in water, where it is found in its ionized form [1]. The main sources of fluoride in the environment are natural, such as volcanic emissions and marine aerosols [2]. Volcanic regions or regions with geothermal activity present high levels of fluoride in soils and water [3,4]. However, anthropogenic activities such as the use of pesticides, sewage, or industrial discharges cause an increase in fluoride concentration in the environment $[5,6]$.

Fluoride is absorbed by the gastrointestinal route [7,8]. Thus, diet is the main fluoride source. Plant foods, such as cereals, fruits, and vegetables, among others, absorb fluoride mainly from the soil and irrigated water. Kudo and Garrec [9] showed that after adding $22 \mathrm{mg} / \mathrm{L}$ of fluoride in an experimental tank to aquatic plants, the concentration of fluoride in these plants increased up to 35 times in $24 \mathrm{~h}$. The absorption and accumulation capacity of fluoride in plant organisms depends on factors such as soil type and $\mathrm{pH}$. The absorption process is favored in soils with acidic $\mathrm{pH}$ due to fluoride's ionic form [10]. Food fluoride levels vary considerably from country to country [11].

Consumption of plant-based foods, such as cereals, fruits, and vegetables, can lead to high intakes of fluoride $[12,13]$. Fluoride is an essential element that is necessary for enzymatic reactions in the body, as well as in the reduction of dental caries topically [14-16]. The European Food Safety Authority (EFSA) established recommended daily intake (DRI) values for fluoride according to age and sex [17]. The recommended daily intake is defined as the minimum required amount of a nutrient or essential element for the proper functioning of the organism [18]. However, a prolonged and high intake 
of fluoride over time can trigger a series of toxic effects such as myopathy, neurological damage, dental fluorosis, or skeletal fluorosis [2,19]. Currently, Europe does not have an acceptable daily intake limit (ADI) for this ion. However, the Food and Nutrition Board of the American Organization Institute of Medicine established ADI values according to age and sex [20]. The acceptable daily intake is defined as the estimate of the total amount of a chemical substance or element contained in food and/or drinking water that can be ingested daily throughout the life of a person, without appreciable risk to health [18].

\section{Material and Methods}

The material used was washed with laboratory detergent (Alconox, Alconox Inc., NY, USA) and Mili-Q quality distilled water obtained from a filtration system (Millipore, Merck KGaA, Darmstadt, Germany). The use of glass material was avoided to prevent any interferences with fluoride.

\subsection{Samples}

A total of 144 samples of different food types were analyzed. The samples were acquired in large commercial areas and supermarkets on the island of Tenerife (Canary Islands, Spain). The samples were processed immediately after their acquisition. Table 1 shows the number of different samples analyzed.

Table 1. The number of analyzed samples according to the type of food.

\begin{tabular}{ccc}
\hline Group & Food Type & No. Samples \\
\hline \multirow{3}{*}{ Cereals and derivatives } & Rice & 8 \\
& Gofio & 8 \\
& Corn & 8 \\
Fruits & Bread & 8 \\
\hline \multirow{2}{*}{ Tree nuts } & Citrus & 8 \\
& Apples & 8 \\
& Bananas & 8 \\
\hline Mushrooms & Almonds & 8 \\
& Walnuts & 8 \\
\hline \multirow{2}{*}{ Vegetables } & Mushrooms & 8 \\
& Onions & 8 \\
& Lettuce & 8 \\
& Potato & 8 \\
& Tomatoes & 8 \\
Legumes & Carrots & 8 \\
& Bean & 8 \\
& Lentils & 8 \\
& Chickpeas & 8 \\
\hline
\end{tabular}

\subsection{Solutions}

The different solutions used in the treatment of the samples were as follows: 10-1 M fluoride solution was obtained by dissolving $4.199 \mathrm{mg}$ of NaF (Sigma Aldrich, Steinheim, Germany) in $1 \mathrm{~L}$ of distilled water. Buffer solution TISAB (Total Ionic Strength Adjustment Buffer) with CDTA (Cyclohexanediaminetetraacetic Acid Monohydrate) was obtained by dissolving $58 \mathrm{~g}$ of $\mathrm{NaCl}$ (Sigma Aldrich, Steinheim, Germany), $57 \mathrm{~mL}$ of $\mathrm{CH}_{3}-\mathrm{COOH}$ (Sigma Aldrich, Steinheim, Germany), and $4 \mathrm{~g}$ of 1,2-diamine-cyclohexane tetraacetic acid (DCTA) in $500 \mathrm{~mL}$ of deionized water. The $\mathrm{pH}$ was adjusted to 5-5.5. We obtained $8 \mathrm{M} \mathrm{NaOH}$ solution (Sigma Aldrich, Steinheim, Germany) by dissolving $320 \mathrm{~g}$ of $\mathrm{NaOH}$ (Sigma Aldrich, Steinheim, Germany) in distilled water to a total volume of $1 \mathrm{~L}$, and $12 \mathrm{M}$ $\mathrm{HCl}$ solution (Sigma Aldrich, Steinheim, Germany) was obtained by diluting $493.2 \mathrm{~mL}$ of $\mathrm{HCl}$ (Sigma Aldrich, Steinheim, Germany) in $500 \mathrm{~mL}$ of distilled water. 


\subsection{Treatment of the Samples}

Previously homogenized samples of $0.50 \mathrm{~g}$ each were weighed in nickel crucibles $(0.6 \mathrm{~mm}$ thick and $50 \mathrm{~mL}$ capacity). The samples were subjected to digestion in basic medium [21-23], adding $8 \mathrm{~mL}$ of $8 \mathrm{M} \mathrm{NaOH}$ and were left in an oven (Nabertherm, Lilienthal, Germany) for $24 \mathrm{~h}$ at $80{ }^{\circ} \mathrm{C}$. Subsequently, they were placed in a muffle furnace (Nabertherm, Lilienthal, Germany) with two temperature-time programs, the first being $16 \mathrm{~h}$ at $200{ }^{\circ} \mathrm{C}$, and the second being $3 \mathrm{~h}$ at $525^{\circ} \mathrm{C}$. The ashes obtained were dissolved in distilled water and their $\mathrm{pH}$ was neutralized with a $12 \mathrm{M} \mathrm{HCl}$ solution. The content was filtered and transferred to a $25 \mathrm{~mL}$ plastic volumetric flask. Filtering was necessary to remove insoluble cation oxides such as $\mathrm{Si}, \mathrm{Fe}, \mathrm{Al}, \mathrm{Ca}$, and $\mathrm{Mg}$, which could disrupt the measurement [21].

\subsection{Analysis Method}

Potential measurements were obtained using a digital potentiometer with a fluoride selective ion electrode (Crison, Bercelona, Spain), coupled with a magnetic stirrer.

The standard addition method was used to determine the fluoride concentration in the solution, measuring the fluoride concentration before and after the addition of a known amount of fluoride. Furthermore, $6 \mathrm{~mL}$ of TISAB-DCTA buffer solution was added to the solution in order to adjust the ionic strength [23] and the potential difference was measured. The fluoride molar concentration was obtained as follows:

$$
\text { Fluoride concentration }(\mathrm{M})=\mathrm{Cs} \cdot[\mathrm{Vs} /(\mathrm{Vp}+\mathrm{Vs})] /\left[10^{\Delta \mathrm{E} / \mathrm{S}}-((\mathrm{Vp}+\mathrm{Vs}) / \mathrm{Vp})\right]
$$

where $\mathrm{Cs}$ is the fluoride concentration of the added solution (M), Vp is the volume of the analyzed solution $(\mathrm{mL}), \mathrm{Vs}$ is the volume of the added solution $(\mathrm{mL}), \Delta \mathrm{E}$ is the the potential difference of the measured $(\mathrm{mV})$, and $\mathrm{S}$ is the slope of the electrode $(\mathrm{mV})$.

With the molecular weight of the ion, the volume of the solution, and the quantity of food initially used, the concentration of fluoride $(\mathrm{mg} / \mathrm{kg}$ ) was obtained for each analyzed food.

\subsection{Statistical Analysis}

The statistical analyses were performed using IBM Statistic SPSS 23.0 software (Statistical Package for the Social Sciences) (IBM, NY, USA) for Windows ${ }^{\mathrm{TM}}$.

The Kolmogorov-Smirnov and Shapiro-Wilk tests were applied to check if the analyzed data followed a normal distribution [24]. The Levene statistic was used to check the homogeneity of the variances for each of the analyzed parameters [25]. When the data followed a normal distribution, parametric tests were used through the one-way ANOVA (analysis of variance) test. For the data that did not follow a normal distribution, a non-parametric study was performed using the Kruskal-Wallis test and the Mann-Whitney $\mathrm{U}$ test.

These statistical analyses were performed to confirm the existence of significant differences between the different food groups in this study $(p<0.05)$ [26].

\subsection{Dietary Intake Assessment}

The dietary intake was assessed by calculating the estimated daily intake (EDI), calculated as:

$$
\mathrm{EDI}(\mathrm{mg} / \text { day })=\text { Fluoride concentration }(\mathrm{mg} / \mathrm{kg}) \times \text { Consumption }
$$

Once the EDI was calculated, the contribution percentage was obtained considering the recommended and maximum fluoride values established by EFSA [17] and IOM (Institute of Medicine) [20], respectively.

$$
\text { Contribution }(\%)=[\text { EDI/Guideline value }] \times 100
$$




\section{Results and Discussion}

\subsection{Fluoride Levels in the Different Food Groups Analyzed}

Table 2 shows the mean concentrations, standard deviations, and maximum and minimum values of the analyzed samples.

Table 2. Fluoride concentration, standard deviation, and maximum and minimum values found in the analyzed samples.

\begin{tabular}{cccc}
\hline \multirow{2}{*}{ Group } & Food Type & $\begin{array}{c}\text { Concentration } \pm \text { SD } \\
(\mathbf{m g} / \mathbf{k g})\end{array}$ & Max-Min \\
\hline \multirow{3}{*}{ Cereals and derivatives } & Rice & $2.28 \pm 0.93$ & $3.62-0.53$ \\
& Gofio & $1.44 \pm 0.66$ & $2.32-0.53$ \\
& Corn & $1.10 \pm 0.91$ & $3.24-0.50$ \\
& Bread & $2.54 \pm 0.85$ & $3.62-1.23$ \\
\hline \multirow{2}{*}{ Fruits } & Citrus & Not detected \\
& Apples & $1.72 \pm 0.73$ & \\
\cline { 2 - 4 } Tree nuts & Bananas & $3.70 \pm 0.96$ & $1.98-0.86$ \\
\hline \multirow{2}{*}{ Mushrooms } & Almonds & $3.53 \pm 0.62$ & $4.80-2.32$ \\
& Walnuts & $1.28 \pm 0.29$ & $1.15-2.79$ \\
\hline \multirow{2}{*}{ Vegetables } & Mushrooms & $0.01 \pm 0.02$ & $0.06-0$ \\
& Onions & $0.08 \pm 0.05$ & $0.16-0.08$ \\
& Lettuce & $0.99 \pm 1.90$ & $3.53-0$ \\
& Potato & $0.96 \pm 0.55$ & $2.14-0.40$ \\
& Tomatoes & $0.04 \pm 0.01$ & $0.04-0$ \\
\hline \multirow{2}{*}{ Legumes } & Carrots & $1.05 \pm 1.79$ & $3.86-0$ \\
& Bean & $0.32 \pm 0.66$ & $1.84-0$ \\
& Lentils & $0.68 \pm 1.41$ & $1.36-0$ \\
\hline
\end{tabular}

Walnuts were the food group in which the highest concentrations of fluoride were registered among all the groups studied. Almonds $(3.70 \pm 0.96 \mathrm{mg} / \mathrm{kg})$ and walnuts $(3.53 \pm 0.62 \mathrm{mg} / \mathrm{kg})$ registered the highest mean levels of fluoride. The highest concentration recorded in these foods may be due to the concentration of elements that occurs after desiccating tree nuts [27]. The New Zealand Total Diet Study (NZTDS), carried out in 2016 by the Ministry for Primary Industries (MPI), registered an average concentration of fluoride in almonds of $5.66 \mathrm{mg} / \mathrm{kg}$, higher than that found in this study [28,29]. The differences in the origin of the sample have a considerable influence on the level of fluoride registered in the walnuts.

The studied cereals and derivatives presented the following descending concentration sequence: bread $>$ rice $>$ gofio $>$ corn. The level of fluoride registered in bread $(2.54 \pm 0.85 \mathrm{mg} / \mathrm{kg})$ and rice $(2.28 \pm 0.93 \mathrm{mg} / \mathrm{kg})$ stood out considerably. Levels found by Liteplo et al. [10] in baked goods and cereals were between 0.04 and $1.85 \mathrm{mg} / \mathrm{kg}$, lower than those registered in the present study. Battacharya et al. [30], in rice cultivated in two regions in western India, registered concentrations of $0.56 \pm 0.14 \mathrm{mg} / \mathrm{kg}$ (Bankura) and $0.83 \pm 0.19 \mathrm{mg} / \mathrm{kg}$ (Purulia); in both cases, these values are lower than those registered in the present study. Jha et al. [31] recorded higher levels in rice cultivated in other regions of India ranging from $6.7 \pm 0.6$ to $12.0 \pm 0.9 \mathrm{mg} / \mathrm{kg}$. The differences in the fluoride content recorded in the rice samples depend on the crop area.

In the fruit group, fluoride was detected only in bananas, registering an average level of $1.72 \pm 0.73 \mathrm{mg} / \mathrm{kg}$. Notably, banana is a fruit with a high percentage of water. 
Statistical analysis revealed the existence of significant differences $(p<0.05)$ in the fluoride content between almonds and walnuts compared with the rest of the analyzed foods. Statistical differences were found between bread and rice compared with the rest of the foods.

\subsection{Assessment of the Fluoride Intake}

Table 3 shows the estimated daily intake of fluoride by type of food, as well as the percentages of contribution to the recommended daily intake (DRI).

The consumption of $100 \mathrm{~g}$ per day of the analyzed foods ensures contribution percentages of $0.17-61.7 \%$ of the DRI set at $0.6 \mathrm{mg} /$ day for boys and girls aged $1-3$ years [17]. The percentage of contribution from the consumption of almonds $(61.7 \%)$, walnuts $(58.3 \%)$, bread $(42.3 \%)$, and rice $(38.0 \%)$ stood out considerably. At these ages, boys and girls consume greater amounts of food such as bread and rice, with which the established DRI may be exceeded. Thus, with a consumption of $236 \mathrm{~g} /$ day of bread or $263 \mathrm{~g} /$ day of rice, $100 \%$ of the DRI set for this age group would be reached. Considering the maximum intake value was established by IOM [20] at $1.3 \mathrm{mg} /$ day for children of 1-3 years, it would be necessary to consume $511 \mathrm{~g} /$ day of bread or $570 \mathrm{~g} /$ day of rice. In the case of rice, it is necessary to consider that its preparation needs water. Normally, tap water is used for cooking; therefore, the regions with high concentrations of fluoride in water, such as the Canary Islands, will have high levels of fluoride in cooked rice. It is recommended, in the case of children, that bottled water be used to prepare this type of food or to reduce the consumption of rice.

Adolescents (15-17 years old) and adults are the groups that record the lowest percentages of contribution to the DRI (under 13.2\%). Therefore, these groups are not at risk of exceeding the fixed values of DRI and ADI. 
Table 3. Values of estimated daily intake (EDI) and contribution percentages (\%) to the dietary recommended intake (DRI).

\begin{tabular}{|c|c|c|c|c|c|c|c|c|c|c|c|c|c|c|c|}
\hline \multirow{4}{*}{ Group } & \multirow{4}{*}{ Food } & \multirow{4}{*}{$\begin{array}{c}\text { Conc } \pm \text { SD } \\
(\mathrm{mg} / \mathrm{kg})\end{array}$} & \multirow{4}{*}{$\begin{array}{c}\text { EDI * } \\
\text { (mg/day) }\end{array}$} & \multicolumn{12}{|c|}{ Contribution (\%) to DRI ** } \\
\hline & & & & \multirow{2}{*}{\multicolumn{2}{|c|}{ 1-3 years }} & \multicolumn{4}{|c|}{ Children } & \multirow{2}{*}{\multicolumn{2}{|c|}{ 11-14 years }} & \multirow{2}{*}{\multicolumn{2}{|c|}{$\begin{array}{c}\text { Teens } \\
\text { 15-17 years }\end{array}$}} & \multirow{2}{*}{\multicolumn{2}{|c|}{ Adults }} \\
\hline & & & & & & $4-6$ & ears & $7-1$ & ears & & & & & & \\
\hline & & & & Boy & Girl & Boy & Girl & Boy & Girl & Boy & Girl & Boy & Girl & Men & Women \\
\hline \multirow{4}{*}{$\begin{array}{l}\text { Cereals and } \\
\text { derivatives }\end{array}$} & Rice & $2.28 \pm 0.93$ & 0.228 & \multicolumn{2}{|c|}{38.0} & 22.8 & 25.3 & 15.2 & 16.3 & 10.4 & 9.91 & 7.13 & 8.14 & 6.71 & 7.86 \\
\hline & Gofio & $1.44 \pm 0.66$ & 0.144 & \multicolumn{2}{|c|}{24.0} & 14.4 & 16.0 & 9.60 & 10.3 & 6.55 & 6.26 & 4.50 & 5.14 & 4.24 & 4.97 \\
\hline & Corn & $1.10 \pm 0.91$ & 0.110 & \multicolumn{2}{|c|}{18.3} & 11.0 & 12.2 & 7.33 & 7.86 & 5.00 & 4.78 & 3.44 & 3.93 & 3.24 & 3.79 \\
\hline & Bread & $2.54 \pm 0.85$ & 0.254 & \multicolumn{2}{|c|}{42.3} & 25.4 & 28.2 & 16.9 & 18.1 & 11.5 & 11.0 & 7.94 & 9.07 & 7.47 & 8.76 \\
\hline Fruits & Banana & $1.72 \pm 0.73$ & 0.172 & \multicolumn{2}{|c|}{28.7} & 17.2 & 19.1 & 11.5 & 12.3 & 7.82 & 7.48 & 5.38 & 6.14 & 5.06 & 5.93 \\
\hline \multirow{2}{*}{ Tree nuts } & Almonds & $3.70 \pm 0.96$ & 0.370 & \multicolumn{2}{|c|}{61.7} & 37.0 & 41.1 & 24.6 & 26.4 & 16.8 & 16.1 & 11.6 & 13.2 & 10.9 & 12.8 \\
\hline & Walnuts & $3.53 \pm 0.62$ & 0.353 & \multicolumn{2}{|c|}{58.3} & 35.3 & 39.2 & 23.5 & 25.2 & 16.1 & 15.3 & 11.0 & 12.6 & 10.4 & 12.2 \\
\hline Mushrooms & Mushrooms & $1.28 \pm 0.29$ & 0.128 & \multicolumn{2}{|c|}{21.3} & 12.8 & 14.2 & 8.53 & 9.14 & 5.82 & 5.57 & 4.00 & 4.57 & 3.76 & 4.41 \\
\hline \multirow{5}{*}{ Vegetables } & Onions & $0.01 \pm 0.02$ & 0.001 & \multicolumn{2}{|c|}{0.17} & 0.10 & 18.9 & 0.07 & 0.07 & 0.05 & 0.04 & 0.03 & 0.04 & 0.03 & 0.03 \\
\hline & Lettuce & $0.08 \pm 0.05$ & 0.008 & \multicolumn{2}{|c|}{1.33} & 0.80 & 0.89 & 0.53 & 0.57 & 0.36 & 0.35 & 0.25 & 0.30 & 0.24 & 0.28 \\
\hline & Potato & $0.99 \pm 1.90$ & 0.099 & \multicolumn{2}{|c|}{16.5} & 9.90 & 11.0 & 6.60 & 7.07 & 4.50 & 4.30 & 3.10 & 3.54 & 2.91 & 3.41 \\
\hline & Tomatoes & $0.96 \pm 0.55$ & 0.096 & \multicolumn{2}{|c|}{16.0} & 9.60 & 10.7 & 6.40 & 6.86 & 4.36 & 4.17 & 3.00 & 3.43 & 2.82 & 3.31 \\
\hline & Carrots & $0.04 \pm 0.01$ & 0.004 & \multicolumn{2}{|c|}{0.67} & 0.40 & 0.44 & 0.27 & 0.30 & 0.18 & 0.17 & 0.13 & 0.14 & 0.12 & 0.14 \\
\hline \multirow{3}{*}{ Legumes } & Alubias & $1.05 \pm 1.79$ & 0.105 & \multicolumn{2}{|c|}{17.5} & 10.5 & 11.7 & 7.00 & 7.50 & 4.77 & 4.57 & 3.28 & 3.75 & 3.09 & 3.62 \\
\hline & Lentils & $0.32 \pm 0.66$ & 0.032 & \multirow{2}{*}{\multicolumn{2}{|c|}{5.33}} & 3.20 & 3.56 & 2.13 & 2.30 & 1.45 & 1.39 & 1.00 & 1.14 & 0.94 & 1.10 \\
\hline & Chickpeas & $0.68 \pm 1.41$ & 0.068 & & & 6.80 & 7.56 & 4.53 & 4.86 & 3.10 & 2.96 & 2.13 & 2.43 & 2.00 & 2.34 \\
\hline
\end{tabular}

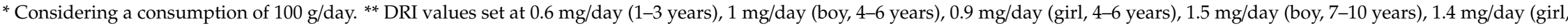

7-10 years), $2.2 \mathrm{mg} /$ day (boy, 11-14 years), $2.3 \mathrm{mg} /$ day (girl, $11-14$ years), $3.2 \mathrm{mg} /$ day (boy, $15-17$ years), $2.8 \mathrm{mg} /$ day (girl, $15-17$ years); $3.4 \mathrm{mg} / \mathrm{day}$ (men) and $2.9 \mathrm{mg} / \mathrm{day}$ (women) [17]. 


\section{Conclusions}

The foods with the highest levels of fluoride were almonds, walnuts, bread, and rice. Significant differences $(p<0.05)$ were detected in the fluoride content between almonds and walnuts compared with the rest of the foods, as well as differences between rice and bread compared with the rest of the analyzed foods.

Children between 1 and 3 years of age are more exposed to fluoride because they need lower amounts of this element and the consumption of some foods in this population group may be higher. Thus, the consumption of rice can cause a possible risk for the health of children (1-3 years) if tap water is used in the preparation of this food. This water can contain high levels of fluoride, which may lead to the excess of this element in the daily diet. It is recommended to reduce the consumption of rice in children from 1 to 3 years old or prepare rice with bottled water. The adolescent and adult population is not at risk because the consumption of $100 \mathrm{~g} /$ day of the analyzed food does not entail exceeding the DRI or ADI values.

Author Contributions: A.H. and J.R.J. conceived and designed the experiments; J.R.J. performed the experiments; Á.J.G. analyzed the data; Á.J.G. and A.H. contributed reagents/materials/analysis tools; S.P. and C.R. wrote the paper. All authors have read and agreed to the published version of the manuscript.

Funding: This research received no external funding.

Conflicts of Interest: The authors declare no conflict of interest.

\section{References}

1. Christe, K.; Schneider, S. Fluorine, Chemical Element; Encyclopædia Britannica: London, UK, 2018.

2. Kazi, T.G.; Brahman, K.D.; Baig, J.A.; Afridi, H.I. Bioaccumulation of arsenic and fluoride in vegetables from growing media: Health risk assessment among different age groups. Environ. Geochem. Health 2019, 41, 1223-1234. [CrossRef]

3. Camargo, J.A. Fluoride toxicity to aquatic organisms: A review. Chemosphere 2003, 50, 251-264. [CrossRef]

4. Rubio, C.; Rodríguez, I.; Jaudenes, J.R.; Gutiérrez, A.J.; Paz, S.; Burgos, A.; Hardisson, A.; Revert, C. Fluoride levels in supply water from a volcanic area in the Macaronesia region. Environ. Sci. Poll. Res. 2020, 27, 11587-11595. [CrossRef]

5. Dagnaw, L.A.; Chandravanshi, B.S.; Zewge, F. Fluoride Content of Leafy Vegetables, Irrigation Water, and Farmland Soil in the Rift Valley and in Non-Rift Valley Areas of Ethiopia. Res. Report Fluor. 2017, 50, 409-429.

6. Kibet, B.; Jackson, C.K.; Cheruiyot, M.Y.; Munyendo, W.L.L.; Ambrose, K.; Oindo, A.G. Assessment of Fluoride and selected heavy metals in food chain around Fluorspar mining Plant, Kenya. Green J. Environ. Manag. Public Safe 2019, 8, 15-24.

7. Sampaio, C.; Botazzo-Delbem, A.C.; de Assis-Salama, I.C.; Cunha, R.F.; Pessan, J.P. Fluoride Concentrations in Commercially Available Processed Beverages in Brazil Consumed by Infants. Fluoride 2019, 52, 467-473.

8. Zohoori, F.V.; Maguire, A. Database of the Fluoride (F) Content of Selected Drinks and Foods in the UK and Ireland; Newcastle University: Newcastle Upon Tyne, UK; Teesside University: Middlesbrough, UK, 2019.

9. Kudo, A.; Garrec, J.P. Accidental release of fluoride into experimental pond and accumulation in sediments, plants, algae, molluscs and fish. Reg. Toxicol. Pharmacol. 1983, 3, 189-198. [CrossRef]

10. Liteplo, R.; Gomes, M.R.; Canada, H.; Ottawa, C.; Howe, M.P.; Malcolm, M.H. Environmental Health Criteria 227: Fluorides; World Health Organization: Geneva, Switzerland, 2002.

11. Cantoral, A.; Luna-Villa, L.C.; Mantilla-Rodríguez, A.A.; Mercado, A.; Lippert, F.; Liu, Y.; Peterson, K.E.; Hu, H.; Téllez-Rojo, M.M.; Martínez-Mier, E.A. Fluoride Content in Foods and Beverages From Mexico City Markets and Supermarkets. Food Nutr. Bull. 2019, 40, 514-531. [CrossRef]

12. Gupta, P.; Gupta, N.; Meena, K.; Moon, N.J.; Kumar, P.; Kaur, R. Concentration of Fluoride in Cow's and Buffalo's Milk in Relation to Varying Levels of Fluoride Concentration in Drinking Water of Mathura City in India-A Pilot Study. J. Clin. Diagn. Res. 2015, 9, LC05-LC07. [CrossRef]

13. Zohoori, F.V.; Maguire, A. Development of a database of the fluoride content of selected drinks and foods in the UK. Caries Res. 2016, 50, 331-336. [CrossRef] [PubMed] 
14. Castillo-Larrea, D.L. Grado de Desmineralización Dentaria que se Produce por la Exposición a jugo de Limón Artificial: Estudio In-Vitro. Bachelor's Thesis, Facultad de Odontología, Universidad de Las Americas, Quito, Ecuador, 2014.

15. Paz, S.; Jáudenes, J.R.; Gutiérrez, A.J.; Rubio, C.; Hardisson, A.; Revert, C. Determination of Fluoride in Organic and Non-organic Wines. Biol. Trace Elem. Res. 2017, 178, 153-159. [CrossRef] [PubMed]

16. Townsend, J.A.; Thompson, T.; Vaughn, S.; Wang, Y.; Yu, Q.; Xu, X.; Wen, Z.T. Analysis of Fluoride Content in Alternative Milk Beverages. J. Clin. Ped. Dent. 2019, 43, 388-392. [CrossRef]

17. EFSA (European Food Safety Authority). Scientific Opinion on Dietary Intake Reference Values for fluoride. EFSA J. 2013, 11, 3332.

18. Castro, G.D. Dependencia de la dosis en los mecanismos de toxicidad y la evaluación de riesgo en toxicología. Act. Bioquím. Clín. Latin. 2013, 47, 561-585.

19. Sawangjang, B.; Takizawa, S. Assessment of Fluoride Intake from Rice Consumption by Using Tap Water Containing Fluoride for Rice Soaking Water. J. Water Environ. Tech. 2020, 18, 117-131. [CrossRef]

20. IOM (Institute of Medicine) Standing Committee on the Scientific Evaluation of Dietary Reference Intakes; Food and Nutrition Board of the Institute of Medicine, Food and Nutrition Board. Dietary Reference Intakes (DRIs): Recommended Intakes for Individuals Elements; National Academy Press: Washington, DC, USA, 2004.

21. Pérez-Olmos, R. Elementos traza en alimentos: Determinación del contenido de fluoruros en tés. Aliment. Rev. Tecn. Hig. Alim. 1985, 162, 57-61.

22. Kjellevold, M.M.; Bjorvatn, K.; Julshamn, K. Determination of fluoride in food by the use of alkali fusion and fluoride ion-selective electrode. Food Chem. 2001, 73, 373-379. [CrossRef]

23. Rocha-Barrasa, R.A. Fluoruro en Alimentos: Contenidos, Bioaccesibilidad y Absorción por el Epitelio Intestinal. Ph.D. Thesis, Universidad Politécnica de Valencia, Valencia, Spain, December 2013.

24. Razali, N.M.; Wah, Y.B. Power comparisons of Shapiro-Wilk, Kolmogorov-Smirnov, Lilliefors and Anderson-Darling Tests. J. Stat. Model. Anal. 2011, 2, 21-33.

25. Howard, B.L.; Gary, S.K.; Alberto, F.R. A Monte Carlo study of seven homogeneity of variance test. J. Math. Stat. 2010, 6, 359-366.

26. Sheskin, D.J. Handbook of Parametric and Nonparametric Statistical Procedures; CRC Press: Boca Raton, FL, USA, 2004.

27. Bennett, L.E.; Singh, D.P.; Clingeleffer, P.R. Micronutrient mineral and folate content of Australian and imported dried fruit products. Crit. Rev. Food Sci. Nutr. 2011, 51, 38-49. [CrossRef]

28. New Zealand Total Diet Study. Available online: http://foodsafety.govt.nz/policy-law/food-monitoringprogrammes/total-diet-study/ (accessed on 2 May 2020).

29. Watts, C. Fluoride Intakes of 9-10-year-old Children Living in Fluoridated and non-Fluoridated Areas of Dunedin and Timaru-A pilot Study. Master's Thesis, University of Otago, Dunedin, New Zealand, June 2018.

30. Battacharya, P.; Samal, A.C.; Banerjee, S.; Pyne, J.; Santra, S.C. Assessment of potential health risk of fluoride consumption through rice, pulses, and vegetables in addition to consumption of fluoride-contaminated drinking water of West Bengal, India. Environ. Sci. Pollut. Res. 2017, 24, 20300-20314. [CrossRef]

31. Jha, S.K.; Nayak, A.K.; Sharma, Y.K. Site specific toxicological risk from fluoride exposure through ingestion of vegetables and cereal crops in Unnao district, Uttar Pradesh, India. Ecotoxicol. Environ. Toxicol. 2011, 74, 940-946. [CrossRef] [PubMed]

(C) 2020 by the authors. Licensee MDPI, Basel, Switzerland. This article is an open access article distributed under the terms and conditions of the Creative Commons Attribution (CC BY) license (http://creativecommons.org/licenses/by/4.0/). 